\title{
Intrinsic Radiolabeling of Nutrients for Human Nutrition Studies Using Accelerator Mass Spectrometry
}

A.J. Clifford, S.R. Dueker, E.E. Fabbro, Y. Lin, N. Hong, M.W. Lamé, H.J. Segall, B.A. Buchholz and J.S. Vogel

This article was submitted to

$3^{\text {rd }}$ International Conference on Isotopes

Vancouver, British Columbia, Canada

U.S. Department of Energy

September 6-10, 1999

Lawrence

Livermore

National

Laboratory

January 31, 2000 


\section{DISCLAIMER}

This document was prepared as an account of work sponsored by an agency of the United States Government. Neither the United States Government nor the University of California nor any of their employees, makes any warranty, express or implied, or assumes any legal liability or responsibility for the accuracy, completeness, or usefulness of any information, apparatus, product, or process disclosed, or represents that its use would not infringe privately owned rights. Reference herein to any specific commercial product, process, or service by trade name, trademark, manufacturer, or otherwise, does not necessarily constitute or imply its endorsement, recommendation, or favoring by the United States Government or the University of California. The views and opinions of authors expressed herein do not necessarily state or reflect those of the United States Government or the University of California, and shall not be used for advertising or product endorsement purposes.

This is a preprint of a paper intended for publication in a journal or proceedings. Since changes may be made before publication, this preprint is made available with the understanding that it will not be cited or reproduced without the permission of the author.

This report has been reproduced directly from the best available copy.

Available to DOE and DOE contractors from the

Office of Scientific and Technical Information

P.O. Box 62, Oak Ridge, TN 37831

Prices available from (423) 576-8401

http:/ / apollo.osti.gov/bridge/

Available to the public from the National Technical Information Service

U.S. Department of Commerce 5285 Port Royal Rd., Springfield, VA 22161 http://www.ntis.gov/

OR

Lawrence Livermore National Laboratory Technical Information Department's Digital Library http://www.llnl.gov/tid/Library.html 


\title{
INTRINSIC RADIOLABELING OF NUTRIENTS FOR HUMAN NUTRITION STUDIES USING ACCELERATOR MASS SPECTROMETRY
}

\author{
Andrew J. Clifford ${ }^{1}$, Stephen R. Dueker ${ }^{1}$, Elisabetta E. Fabbro ${ }^{1}$, Yumei Lin ${ }^{1}$, \\ Nichole Hong ${ }^{1}$, Michael W. Lamé ${ }^{2}$, Henry J. Segall ${ }^{2}$, Bruce A. Buchholz ${ }^{3}$, John S. \\ Vogel 1,3 .
}

Department of Nutrition ${ }^{1}$ and Molecular Biosciences ${ }^{2}$ Univ of Cal, Davis, CA; and Center for Accelerator Mass Spectrometry $^{3}$, Lawrence Livermore National Laboratory, Livermore, CA

${ }^{14} \mathrm{C}$ labeling of plant nutrients coupled with detection of label by Accelerator Mass Spectrometry (AMS) represents an attractive means for investigating the metabolism of nutrients that are an intrinsic part of a food or diet [1,2]. AMS quantitates attomolar concentrations of ${ }^{14} \mathrm{C}$-labeled substrates from biologic tissues and fluids at ethically acceptable levels of radiation exposure, eliminating the need for compounds of high isotopic concentration. Accordingly, the generic photosynthetic labeling of plants with ${ }^{14} \mathrm{CO}_{2}$ can be used to provide an inventory of difficult to synthesize phytochemicals that can be isolated and tested in their natural form. To assess the intrinsic bioavailability of nutrients as they are consumed within the diet requires labeling strategies that deliver specific, committed precursors in a biochemical pathway. These precursors can be delivered by hydroponic culture or through their leaves and stems by surface application or injection into the xylem flow. We have used some of these labeling strategies with spinach and kale, two commonly consumed leafy vegetables, to produce ${ }^{14} \mathrm{C}$-labeled caroteneoids and folates, respectively.

PHOTOSYNTHETIC RADIOLABELING (BETA-CAROTENE AND LUTEIN): The carotenoid (plant pigments that serve as vitamin A precursors and biological antioxidants) content of spinach (Spinacia oleracea) is distributed between $\beta$ carotene and lutein. ${ }^{14} \mathrm{C}$ - $\beta$-carotene and ${ }^{14} \mathrm{C}$-lutein was prepared by growing spinach in an atmospherically sealed labeling chamber (LC) pulsed with ${ }^{14} \mathrm{CO}_{2}$. (Fig 1). Photosynthetic labeling using ${ }^{14} \mathrm{CO}_{2}$ results in randomly labeled biomolecules and other applications have been described [3,4,5]. Several plants were grown on a 12-h light cycle under metal halide lights supplemented with tungsten illumination in a plant growth box. At 30 days, they were placed in the 
LC. Plants were allowed to equilibrate for one day prior to the administration of ${ }^{14} \mathrm{CO}_{2}$. A total of $50 \mathrm{mCi}$ of ${ }^{14} \mathrm{CO}_{2}$ that was provided at the rate of $10 \mathrm{mCi} / \mathrm{d}$ for 5 days. Exposure was initiated on the first day by adding $10 \mathrm{mCi}$ as a solution of ${ }^{14} \mathrm{C}_{-} \mathrm{NaHCO}_{3}$ to $18 \mathrm{~N} \mathrm{H}_{2} \mathrm{SO}_{4}$ over a $4 \mathrm{hr}$ period releasing ${ }^{14} \mathrm{CO}_{2}$. This level of exposure was repeated for the following 4 days. Following the final exposure, the plants were maintained for $72 \mathrm{~h}$ in LC prior to harvesting. The aerial parts of the plant were harvested and were extracted for carotenes. Final radiometric and chemical purity was determined to be greater than $98 \%$ by analytical RP-HPLC. The specific activities were 1.45 and $0.35 \mathrm{mCi} / \mathrm{mmol}$ for lutein and $\beta$-carotene, corresponding to 0.023 and $0.0056{ }^{14} \mathrm{C}$ atoms per molecule, respectively. One subject has been exposed to a $200 \mathrm{nCi}(306 \mathrm{ug}, 444,000 \mathrm{dpm})$ dose of purifed $\beta$ carotene (see Dueker et al. In this compendium). Other compounds of nutritional interest are also being purified for human testing.

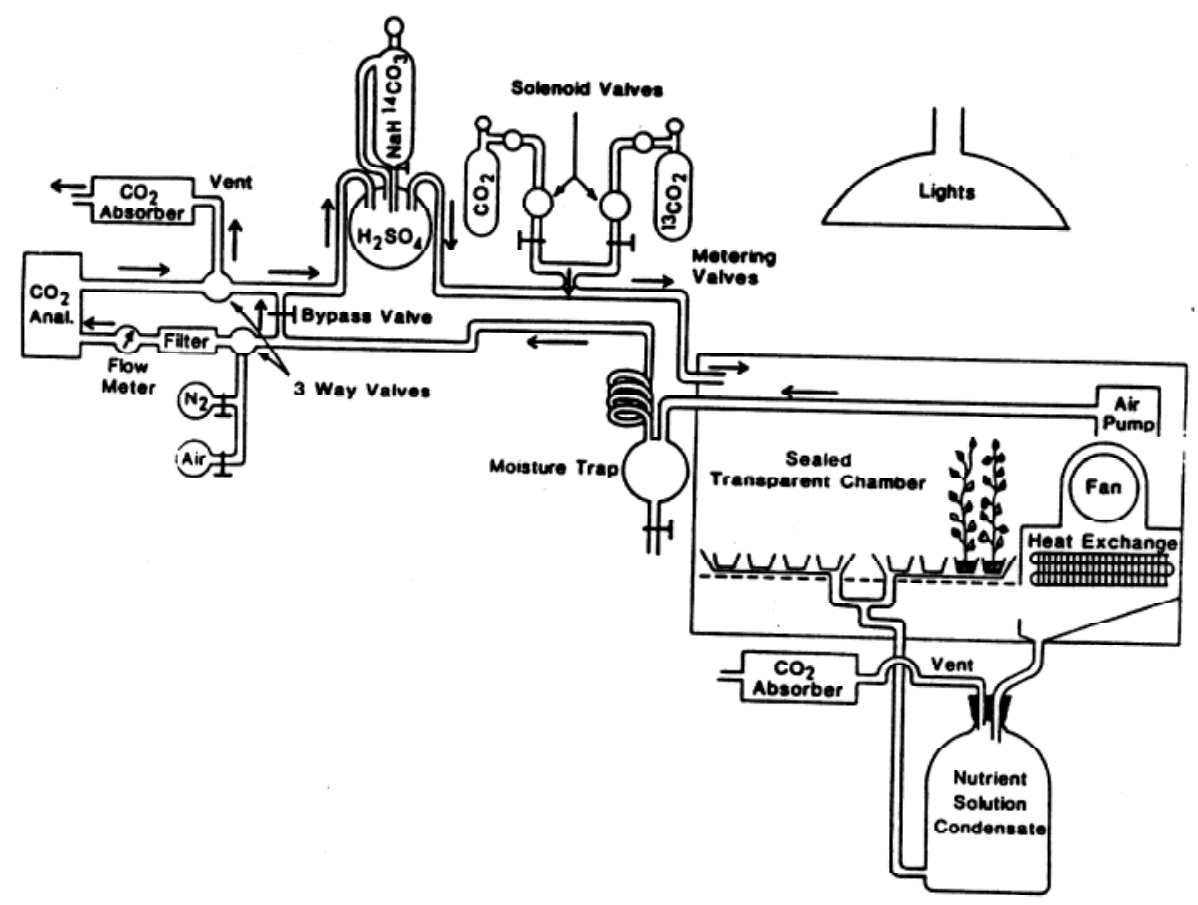

Proc. 3rd Int. Conf. on Isotopes 
Fig 1. Illustration of Plant Labeling Box (3)

COMMITTED PRECURSORS BY COTTON-WICK METHOD (FOLIC ACID): Folic acid (folate) is vitamin needed for one-carbon transfer reactions [6,7]. Kale is a rich source of folic acid but its bioavailability from plant sources is an unsettled issue and this has led to its use as a supplement. To assess the intrinsic bioavailability of folates a kale plant (Brassica oleracea acephala) was grown in an open plant box as described above. At 52-d post germination the plant was administered para-aminobenzoic acid (pABA)(see fig. 2) by the cotton-wick method which entailed the insertion of a cotton thread through the stock of the plant below the first set of leaves, with both ends being inserted into a vial containing ${ }^{14} \mathrm{C}$-pABA $(40 \mu \mathrm{Ci} ; 58 \mathrm{mCi} / \mathrm{mmol})$; labeling began at $11: 30 \mathrm{AM}$ and $500 \mu \mathrm{L}$ of material was taken up completely after 6 hours, at which time the vial was washed with $800 \mu \mathrm{L}$ of water to remove residual material in the vessel and the wick. The plant was then allowed to grow for one week. Aerial parts of the plant were harvested and the bulk of the radioactivity was found to be distributed within the fastest growing shoots and the tips of the larger leaves, verifying that the dose translocation from the site of adminstrations through the plant vascular system. A 2gr sample was ground by mortar and pestle in ice-cold HPLC mobile phase, filtered and a small aliquot (containing 10 DPM of activity) was injected onto an RPHPLC system characterized for folate separation. Fractions were analyzed for ${ }^{14} \mathrm{C}$ by AMS. The metabolite profile showed that less than $\sim 5 \%$ of the label was associated with known folates. 95\% of the activity eluted in the solvent front portion of the chromatogram, which corresponded to either free pABA or polar metabolites. Given the low incorporation of label into folate, the material was not considered appropriate for human experimentation. Further studies are underway to optimize this approach.

CONCLUSION: Photosynthetic labeling of plants with ${ }^{14} \mathrm{CO}_{2}$ yields a wide inventory of low specific activity biomolecules that, given appropriate extraction methods can be purified for use in human studies using AMS. Because only a fraction of the radioactivity is associated with the target molecule(s), the plant cannot be consumed whole to assess the intrinsic bioavailability of the target compounds. Assessment of nutrient bioavailbility from intrinsically labeled plants requires the use of committed biosynthetic precursors. This method demands considerable knowledge of plant biochemistry, and experimentation with a variety of labeling techniques and growth conditions to achieve useful results. It is 
expected that with further experimentation, intrinsic labeling of nutrients by this method with subsequent AMS detection will facilitate investigations into the role of plant matrix on nutrient bioavailability.

This work was performed in part under the auspices of the U.S. Department of Energy by University of California Lawrence Livermore National Laboratory under Contract No. W-7405-Eng-48.

\section{References}

1. Vogel, JS; Turteltaub, KW; Finkel, R; Nelson, DE. (1995) Accelerator mass spectrometry: Isotope quantification at attomole sensitivity. Anal Chem, 67(11):353A - 359A

2. Vogel, JS; Turteltaub, KW. (1998) Accelerator mass spectrometry as a bioanalytical tool in nutrition research. In, Advances in Experimental Medicine and Biology, edited by A.J. Clifford \& H-G. Müller. (New York: Plenum) 397-410.

3. Segall, HJ; Brown, CH; Paige, DFJ. (1983) J Lab Compd Rad, 20: 671-89.

4. Lamé, MW; Wilson, DW; Segall, HJ. (1996) J Lab Compd Rad, 38, No. 12: 1053-60.

5. Dueker SR, Clifford AJ, Lame MW, Segall HJ, Buchholz BA, Vogel JS. (1998) Production of carbon-14 labeled phytonutrients in spinach for human nutrition studies employing accelerator mass spectrometry detection. Faseb J, 12:a210

6. Clifford, JA; Arjomand, A; Dueker, SR; Schneider, PD; Buchholz, BA; Vogel, JS. (1998) The dynaimics of folic acid metabolism in an adult fiven a small tracer dose of $14 \mathrm{C}$-folic acid. In Advances in Experimental Medicine and Biology, edited by A. Clifford and HG Müller. (New York: Plenum) 239-251.

7. Cossins, EA; Chen, L. (1997) Folates and one-carbon metabolism in plants and fungi. Phytochemistry, 45:437-52. 